\title{
CREDIT ACCESSIBILITY TO VULNERABLE SECTIONS: MANAGEMENT PERSPECTIVE
}

\author{
Veerashekharappa*
}

\section{Introduction:}

Despite the vast expansion of the formal credit system in India, the dependence of the rural poor on informal credit institutions continues in some areas especially for meeting the emergency credit requirements. Such dependence is pronounced in the case of marginal farmers, landless labourers, petty traders and rural artisans, etc., particularly in the resourcepoor areas. And credit needs of these sections determined in a complex socio-economic milieu, where it is difficult to adopt project lending approach as followed by banks and where the dividing line between credit for "consumption" and "productive" purposes is blurred (NABARD 1999). It is in this context, peoples' management in making credit to poor assumes significance. The participatory approach bring out the mutual trust and over comes the asymmetric information between the members, which is necessary for initiating banking relationship based on trust and confidence.

Meanwhile, it has been recognized that the credit management programs introduced by Non-Governmental Organizations (NGOs) under Self-Help

* Associate Professor, PGDMS-Sidda Ganga Institute of Technology Tumkur 
Groups (SHGs) as a potential supplementary credit agency for reaching vulnerable section of the society.

The management system adopted by SHGs have comparative advantages over other constituents of the formal credit system in reaching credit to vulnerable sections. As they have following features. Viz.,

- Propagator of voluntarism;

- Practitioner of mutual - help and cooperative principles;

- Promoter of thrift and savings;

- Provider of timely emergency loans and purveyor of development credit.

- Participative lending methodologies

- NABARD had launched a credit accebility programme through new management by linking SHGs and banks, which brought a major change in management of credit to vulnerable sections. This management change has invited attention of many, including policy makers, bankers, donors, NGOs and academicians. In this exercise an attempt is to examine the managerial aspect credit delivery system. The study is presented in two parts, part first exams the management aspect of formal banks in disbursing credit poor.

Part 2nd exams, management of credit to target groups through this programme. The last part brings out summary and conclusion.

\section{Part I}

The financial services, within them management of banking services often been described as a vital for economic development. But, the type of financial systems developed and managed by each country varies, as the countries choose the type of financial system, which is more conducive to growth of the country in a given period.

For instance, there is two extreme cases, in Germany the banks play a dominant role and stock market is not important, where as in United States, the financial market play an important role and the banking industries is less concentrated (Allen and Gale 1995). It has been indicated by several scholars that as economies develop self-financed capital investment first give way to bank-intermediate debt finance and later to the emergence 
of equity markets (Gurly and Shaw 1955, 1960) Gold Smith (1969). Further, the writings of Patrick (1969) McKinon (1973) also emphasis the importance of a strong and efficient financial system in providing growth in developing countries

The importance of credit has been explained by different scholars, among them Belshaw, (1931), according to him the credit as a condition, which enables a person to extend his control as distinct from his ownership of resources. In fact 'credit', it represents the savings mobilised by intermediaries or government from the community and these savings are transformed into capital (Padmanabhan, 1988). The credit is important and necessary for expansion, especially small agriculture and small industry Harsodi (1983) Higgins (1966), since the vast majority of farmers are small holders, developing and organising credit to small holders should attain the raising of economic level. But, the credit from formal credit institutions is not accessible to them. For instance, Griffin (1976) in his analysis demonstrated that Government policies are substantially biased in favor of political groups and the credit worthiness criteria adopted by institutional credit is alienating small borrowers from borrowing, as it is closely linked with collateral against assets. Hoff and Stiglitz (1990) looked into the paradigm of imperfect information and institutional credit. They observed that the power of moneylender is unlikely to be broken by the entry of institutional credit, as these institutions are facing the problem of asymmetric information. Stiglitz and Weiss (1981) analysis support this argument, and further they argue that in a given imperfect information system, raising the interest rate or insisting on a collateral will have an adverse effect on the selection of applicants and increase the risk of the bank loans. Scholars like Milliard (1968) Lipton (1976) Adams (1985), and several others argue that cheap credit will do little unless other inputs being provided. Though the authors looked at the problem in different contexts, the conclusions derived are more or less the same.

In India, to meet the national objective, banks were asked to manage the credit advance to different sectors in terms of amounts in proportion of total credit advanced. This can be said to the first attempt to encourage target oriented lending to priority sectors (Shajan, 1998). In 1980, the composition of priority sector was reviewed under the Chairmanship of Krishnaswamy. The committee identified two major shortcomings viz, 
uniformity is lacking in classification of priority sector and credit has cornered by more affluent sections of the society. In order to rectify, committee recommended to incorporation of the concept of weaker section. Accordingly, at least 50 percent of direct farm credit should be provided for weaker sections including small marginal farmers and agriculture labours. To reach the credit to targeted groups, various subsidised credit schemes were introduced, among them, Integrated Rural Development Programme (IRDP). All these, however, did not produce the desired results. As the spread of the banking system, has been uneven across the regions (Nair, 1991; Tandon, 1988, 50-63; Subbarao 1980;90). The proportion of the poor obtaining credit has been lower than their share in the total population. Because, insistence on collateral, which cannot be provided by them, and a widespread belief that they are not bankable (Rajashekhar, 1996; 80); even they obtained it, neither it was timely nor adequate (Vyasulu and Rajashekhar, 1993; Veerashekharappa, 1998, and the transaction cost of borrower is very high and there are economies of scale in the transaction costs, i.e., higher the amount borrowed lower is the transaction cost (Veerashekharappa 1998). Thus, the credit from formal banking institutions is skewed towards the rich, landholders and frequent borrowers.

In addition of above problems, the problem of default, which in turn resulted in mounting overdue and adversely affecting recycling of credit and led to lower profit margins. In fact, the prospective borrowers are identified by the state government officials, who assisted in sanctioning the grant and escorted them to the bank for sanctioning the loan. While the involvement of the extension agents up to this stage was visible and common, their involvement in recovery of loans so granted was most uncommon (Nanda 1994).

\section{Management of group lending}

The Self Help Groups (SHGs) or the Thrift and Credit Groups are mostly informal groups whose members pool savings and re-lend within the group on rotational or need basis. A Self-help is understood widely as a small, homogenous affinity group of people formed voluntarily with the objective of attaining certain collective goals, both social and economic. Such groups may come into existence spontaneously to address some common needs 
or respond to some common problem. In fact, Dr Rangarajan opinion, the linkage programme will be supplementing to the existing formal banking institution. The group lending movement has made inroads around the world, including India. In the process, poor households are being given hope and possibility to improve their lives through their own savings and credit programmes.

The Groups have demonstrated their capacity to carryout thrift and credit operations for productive purpose most successful, if proper guidance and suitable training is given. To supplement their meager resources for credit operation, it has become necessary to link them with banks. Linking the Groups with banks could help in overcoming the problem of high transaction costs by banks in providing credit to the poor, by passing on some banking responsibilities regarding loan appraisal, follow-up and recovery etc., to the groups. In fact, the formal banking sector and informal community based financial institutions or self-help groups represent two ends of the spectrum of credit interventions.

While banks bring in scale and resources to the partnership, savings and credit groups in their ability to reach the poorest of the poor, and their skills in delivering credit efficiently. A partnership between these two would seek to make optimal use of the strengths of each in sustaining the collaborative effort (Gayathri and Suranjana 1999).

\section{About the Pilot Project}

The major objective of the pilot project is to improve the outreach of the credit to the rural poor by way managing thrift among groups. According to guidelines, the group (SHG) should be six months old and involved in credit and saving activities. The group should be homogenous and should function in democratic way. Credit needs of the group are met from self saving or borrowing from banks, bank will consider group savings as security for the loan. The bank will charge 12 per cent as interest and the group will have option to charge to its members. The SHGs can take up micro-finance intermediary and social development activity when they have been asked to do different roles. As financial intermediary it has,

- as money lender, providing quickly small emergent loans but without charging exploitative rate of interest;

- as development banker provides small production and investment credit to the poor for their economic development but without gaining through the 
long procedures, documentation, security requirements, etc., at lesser transaction cost;

- as a cooperative adopts participation approach of mutual cooperatives and joint pressure without the ills of \pm self interest, interference of politicians/ Government Department officials;

- as voluntary agency helping each other through their common efforts; for bringing economic and social upliftment among the poor people.

Based on various studies, it has been obsenved that the intermediation of NGOs and Groups helped banks to reduce the transaction costs by 40 per cent initially and 60 per cent over a period of time and the recovery performance improved to 92 per cent, as the bank personnel gained experience. The different models are evolved to link the programme some of them are presented here:

- Model-I Where, banks lend directly to the ultimate borrowers without having NGOs and SHGs as intermediaries.

- Model-II: Where, banks lend directly to the ultimate borrowers, and NGOs and SHGs are involved as non-financial intermediaries (RBI,Op.cit. 1990, p. 130)

SHGs and NGO help the financing bank on

- Identification

- Preparation of loan application

- Monitoring

- Supervision

- Recovery of loans

- Evolutionary process

- Model III: Where, banks use SHGs as financial intermediaries to lend the credit to the borrowers, with NGOs as non-financial intermediaries.

- Model-IV: Where credit flows from banks to NGOs and then to $S H G$ s before reaching the ultimate borrowers (both NGOs and SHGs) act as financial intermediaries.

\section{Progress of PPLBG}

This section is classified into two sub sections, the sub-section $A$, discusses overall progress of the linkage programme, the sub-section $B$, discusses exclusively Karnataka. 


\section{Section A}

Since initiation the programme, as many as 380 formal banking credit institutions are involved at the end of March, 2005, comprising, commercial banks, RRBs and co-operative banks. Thus in a decades time this programme is achieved a great success by expanding width and length across the country, covering most of the states and union territories. The total number of Groups linked 16,18,476 and benefiting 1.6 crore families. Among them, the women groups constitute about 84 percent of the total. The yearwise achievement is present in Table 1. Though in the beginning only 255 groups were linked but in the later years the number has increased in multiples. However, the amount disbursed under the programme is insignificant, compared to IRDP.

Table 1: Progress of Linkage Programmes (Rs crores)

\begin{tabular}{|l|r|r|r|r|r|}
\hline \multicolumn{7}{|c|}{ Cumulative } \\
\hline Year & $\begin{array}{c}\text { Number of } \\
\text { SHG } \\
\text { Financed }\end{array}$ & $\begin{array}{r}\text { Bank loan } \\
\text { (Rs lakhs) }\end{array}$ & $\begin{array}{c}\text { No of } \\
\text { families } \\
\text { assisted }\end{array}$ & $\begin{array}{r}\text { Average } \\
\text { loan per } \\
\text { SHG(Rs) }\end{array}$ & $\begin{array}{r}\text { Average } \\
\text { loan per } \\
\text { family }\end{array}$ \\
\hline $1992-93$ & 255 & 30 & 4335 & 11765 & 692 \\
$1993-94$ & 365 & 36 & 6205 & 9863 & 580 \\
$1994-95$ & 1502 & 179 & 25534 & 11917 & 701 \\
$1995-96$ & 2635 & 361 & 44795 & 13700 & 806 \\
$1996-97$ & 3841 & 578 & 65297 & 15048 & 885 \\
$1997-98$ & 5719 & 1192 & 97223 & 20843 & 1226 \\
$1998-99$ & 18678 & 3330 & 317526 & 17828 & 1049 \\
$1999-00$ & 81780 & 13590 & 1390260 & 16618 & 978 \\
$2000-01$ & 149050 & 28789 & 2533850 & 19315 & 1136 \\
$2001-02$ & 197653 & 54554 & 3360101 & 27601 & 1624 \\
$2002-03$ & 255882 & 102231 & 3754874 & 26985 & 1799 \\
$2003-04$ & 361731 & 185550 & 4586000 & 36180 & 2412 \\
$2004-05$ & 518173 & 296180 & 7774000 & 42971 & 2864 \\
As on & 1618476 & 6898000 & 24250000 & 42620 & 3404 \\
March 2005 & & & & & \\
\hline
\end{tabular}

Source: RBI (1999) Report on Trend and Progress of Banking Statistics in India 1998-99, RBI p.126.

Note:*loans disbursed by commercial banks and cooperatives. 
Across the region the programme performed betted in the southern region, followed by Eastern region. The better performance in southern region is attributed to better network of NGOs and their involvement in promotion of groups in savings and credit activities. Apart NGOs, the state as well as religion institutions are equally being participated.

- Zilla Panchayat (Zill Panchayat, Belgaum);

- the Agriculture department promoting SHGs under DANIDA assisted WYTEP programme.

- the Karnataka Milk Federation comprising of small dairy farmers; fisheries and forestry departments promoting a few groups in implementation of community participatory programmes;

- the Karnataka State Women Development Corporation implementing a majore IFAD assisted SWASHAKTHI programme.

The Zilla Panchayat of Belgaum has taken initiative in 1997-98 to make the celebration of Golden Jubilee of India Independence. The primary responsibility of promoting Groups was assigned to the Gram Panchayat secretaries and Anganwadi workers who are close to the people and had the feel of the rural psychology. The call was 'one SHG in each Panchayat'. A significant features of this initiative was that a sense of voluntarism was built in among the Government functionaries.

\section{iii) Religious / Charitable Institutions as SHPI}

The religious institutions and church based social service organisation have begun taking the initiative to promote SHGs. The SKDRDP leads among the religious in promoting and linking SHGs. The Taralbalu Rural Development Foundation Chitradurga district is a new entrant in the field. Church-based NGOs such as Nirmal Federation, Bellary Diocesan Development Society (BDDS) have associated themselves in a big way in organising the rural poor on to Groups. Thus, in Karnataka, SHP Institutions are belonging to not only NGOs sector but also from state through its department.

However, the purpose of promotion varies, for instance, the state is promoted them to route its poverty alleviation programme through SHGs, whereas the religious and charitable trusts are promoted SHGs to expand and deepen their religioous, social and welfare activities. The NGOs promotes 
SHGs for multiple purpose from income generating to social activities. However, now all these institutions are involving in the activities of the savings and credit.

\section{Linkages}

Thus, involvement of multiple agencies as Self Help Promotion Institutions (SHPI), contributed for promotion of larger number of SHGs. According to Table, 2, in Karnataka 1,63,219 groups were linked (March 2005), on an average five groups per village and each group got on an average Rs 33000 as bank loan.. The number of banking instifutions are involved in the programme are 16 commercial banks (35 per cent of total), 16 co-operative banks (out of 19) and all RRBs have participating. Thus, yet to couple of banks have to join the programme.

Table 2: SHG-Bank Linkage Programme:

A Comparison between Karnataka and Gujarat, March, 2005

\begin{tabular}{|r|l|r|}
\hline & \multicolumn{1}{|c|}{ Particulars Karnataka } & \\
\hline 1. & Total No. of SHG linked & $1,63,218$ \\
\hline 2. & Total loan disbursed (Rs. in Million) & 5,517 \\
\hline 3. & Loan per SHG (Rs.) & 33,801 \\
\hline 4. & No. of SHGs per village & 5.9 \\
\hline 5. & $\begin{array}{l}\text { No. of SHGs linked per Rural } \\
\text { Financial Institution }\end{array}$ & 19.60 \\
\hline 6. & $\begin{array}{l}\text { Estimated total households } \\
\text { covered by SHGs }\end{array}$ & 22.85 \\
\hline 7. & No. of households per SHG & 63 \\
\hline
\end{tabular}

Source: NABARD 2005.

From the Table 3, it can be noticed that there is a shift in proportion of linkage from model two and three to one, which means the banks are lending directly to the groups, without any agency as via media, this shows that the banks are getting more confidence on groups. The distribution of groups across banks show that, the regional rural banks have more linkages than the commercial banks and cooperative banks. 
Table 3: Credit Distributed to SHGs Across Models (in Million)

\begin{tabular}{|c|cc|cc|c|c|c|c|}
\hline State & \multicolumn{2}{|c|}{ Model-1 } & \multicolumn{2}{c|}{ Model-II } & \multicolumn{2}{c|}{ Model-III } & \multicolumn{2}{c|}{ Total } \\
\cline { 2 - 9 } & 2005 & 2001 & 2005 & 2001 & 2005 & 2001 & 2005 & 2001 \\
\hline Progress & 87,370 & 4159 & 48,716 & 6536 & 27,112 & 3691 & 163,198 & 14,386 \\
& $(54)$ & $(29)$ & $(30)$ & $(45)$ & $(16)$ & $(26)$ & $(100)$ & $(100)$ \\
\hline Credit & 3,199 & 113.8 & 1521 & 175.25 & 781.5 & 78.59 & 5501.5 & 367.65 \\
Distributed & $(58.2)$ & $(31)$ & $(27.6)$ & $(47.7)$ & $(14.2)$ & $(21.4)$ & $(100)$ & $(100)$ \\
\hline
\end{tabular}

Source: NABARD and Microfinance, 2000-01 and

Table 4.5 Financial Institution wise SHG Linkage and Loan Disbursement in Karnataka (March 2005)

(Amount in Rs. Million)

\begin{tabular}{|c|c|c|c|c|c|c|c|c|}
\hline \multirow{2}{*}{ State } & \multicolumn{2}{|c|}{$\begin{array}{c}\text { Commercial } \\
\text { Banks }\end{array}$} & \multicolumn{2}{c|}{$\begin{array}{c}\text { Regional } \\
\text { Rural }\end{array}$} & \multicolumn{2}{c|}{$\begin{array}{c}\text { Cooperative } \\
\text { Banks }\end{array}$} & \multicolumn{2}{c|}{ Total } \\
\cline { 2 - 9 } & SHGs & Loan & SHGs & Loan & SHGs & Loan & SHGs & Loan \\
\hline Karnataka & 54,814 & 2021 & 62,732 & 2197 & 45,652 & 1299 & 163 & 5517 \\
\hline & $(35.2)$ & $(36.5)$ & $(37.5)$ & $(39.9)$ & $(27.3)$ & $(39.9)$ & $(100)$ & $(100)$ \\
\hline
\end{tabular}

\section{Role of NABARD}

NABARD is supporting its implementation, through refinance and promotional grant assistance. According to the Chief of the Regional office of NABARD in Karnataka, the SBLP in a way was sown and germinated in the state of Karnataka. To keep up with same trend, several polices and strategies were being adopted, a State Level Review Committee for Credit Delivery Innovation (SLRCCDI) has been setup. The Committee is consisted of members from government, leading banks and prominent NGOs. This Committee discusses policy issues and a problems concerning innovative efforts like SBLP and suggests remedial measures. Based on the track record of various organizations, recognizes them as SHPIs and provide promotional grant assistance. In Karnataka, presently, 55 NGOs, eight RRBs and 13 DCCBs have been recognized as SHPIs. These instifutions have taken up promotional activities, such as formation, nurturing and facilitating credit linkage of SHGs. Table 4 provides information on the support extended by NABARD to NGOs to act as SHPIs. 
Table 4: Support to NGOs by NABARD in Karnataka (March 2004)

\begin{tabular}{|c|c|c|c|c|}
\hline \multicolumn{4}{|c|}{ Achievements } & \multicolumn{2}{c|}{ (Amount in Rs. Million) } \\
\hline $\begin{array}{c}\text { No. of } \\
\text { NGOs }\end{array}$ & $\begin{array}{c}\text { No. of } \\
\text { SHGs }\end{array}$ & $\begin{array}{c}\text { Sanctioned } \\
\text { Amount }\end{array}$ & $\begin{array}{c}\text { No. of } \\
\text { SHGs }\end{array}$ & Amount \\
\hline 55 & 6812 & 7.46 & 5954 & 4.65 \\
\hline
\end{tabular}

Another major activity of NABARD in promoting SBLP is to build the capacity of various agencies and their personnel. Table 5 provides information about agencywise personnel who were trained under support from NABARD in Karnataka till 2004.

Table 5: Capacity Building by NABARD (March 2004)

\begin{tabular}{|c|c|c|c|c|}
\hline Participants of & Banks & NGOs & Govt. & Total \\
\cline { 2 - 5 } & 7852 & 609 & 50 & 8511 \\
\hline
\end{tabular}

Thus, the regional office of NABARD in Karnataka has taken various measures which have helped in building the awareness and capacities of agencies involved in promoting SBLP and in overall monitoring of the progress of SBLP.

Role of State Government Agencies: The Karnataka state government has laid emphasis on promoting women's participation in the development process. In this context, the Women and Child Development Department (WCDD) has launched a programme called Sthree Shakthi in 2000-01 which aims at formation of women's self- help groups (SHGs). The anganwadi works are expected to form the groups under the programme. Each worker is assigned a target of forming three groups in their respective center. The target group for these SHGs are mainly: a) BPL households, b) landless laborer, c) SCISTs households, and d) households having persons addicted to alcohol or drugs. The Karnataka State Women's Development Corporation (KSWDC) also has promoted SHGs under its Swashakthi Programme in selected districts of the State. The state government, through WCDD has coordinated with NABARD and has taken up capacity building activities under SBLP. NABARD has extended financial support to WCCD to upgrade skills of persons involved in the programme and groups. The linked groups were given frequent trainings on issues like gender, communication skills, 
leadership qualities and book-keeping. Further, Rs 5000 was provided to these groups as a grant / rotating fund after they fulfilled cer tain norms. Some groups were recommended for support under anti poverty programmes like Swarnjayanti Gram Swarozgar Yojana (SGSY). The main objective of SGSY is to bring the poor families above poverty line over a period of time. By March 2005, more than 4106 SHGs had been formed and linked under state sponsored schemes like Swashakti, Swayamsidha, etc.

\section{Financial Institutions :}

As discussed earlier, financial institutions in Karnataka have taken proactive steps in promoting SBLP. Among the commercial banks, the Canara Bank is ahead of all other banks followed by State Bank of India. The Malaprabh a Grameen Bank is at the top among RRBs followed by Cauvery, Tungabhadra and Kalpataru Grameen Banks in that order. Similarly, among co-operatives, the South Canara DCCB is at the top followed by Hassan, Mandya, Tumkur and Bidar DCCBs in that order. Overall, RRBs in Karnataka have played a major role in implementing SBLP. As can be seen from Chart 1, RRBs account for a higher share in terms of SHGs linked, loan disbursed and refinance received from NABARD under SBLP. As mentioned earlier, RRBs have been recognised as SHPI by NABARD.

Chart 1: Share of Different Financial Institutions in SHGs Linked, Loan Disbursed and Refinance obtained in Karnataka

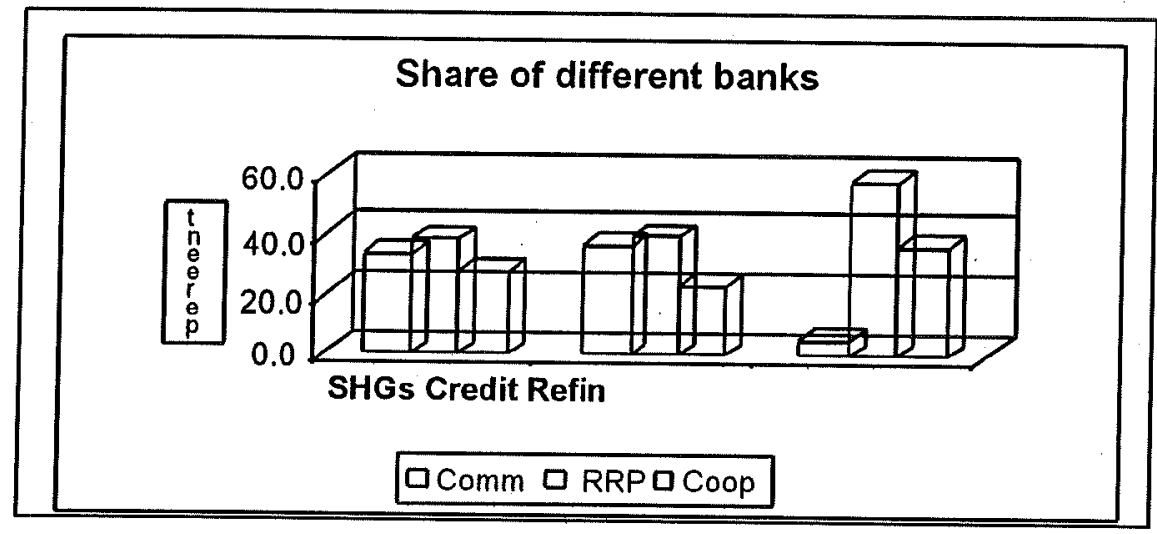




\section{Role of NGO}

Role of Non government Organizations (NGOs): Besides financial institutions, major role played by NGOs like MYRADA and SKRDP has contributed to higher outreach of SHGs in Karnataka. In Karnataka, totally 597 NGOs have been registered. NABARD has selected 67 NGOs as SHPIs which have excellent track of record and have shown willingness to join SBLP. The selected NGOs have undergone training on SBLP before starting the implementation. The selected NGOs have also been assisted with promotional grant by NABARD. However, across districts, the number of NGOs selected by NABARD varies widely. In Koppal and Gulbarga districts only one NGO has been selected. Whereas in Tumkur, ten NGOs have been selected. This variation was found due to non-existence of strong willing NGOs to take up SHPI role. Despite the limited participation of NGOs under NABARD's SHPI, the contribution of NGOs seems to be quite significant. Overall, SHGs formed by NGOs and other development agencies accounted for about 46 percent (Model-II and III) of total SHGs linked in the state. This means, many NGOs have formed and linked a large number SHGs outside the support provided by NABARD for SHPls. Thus, along with financial institutions NGOs also have played a key role in the spread of SBLP in Karnataka. Apart involvement of NGO, banking institutions, the other factors do involve in promotion of the programme. After examining various indicators, we considered three indicator, viz., per capita income, persons served per branch and number of NGOs.

These indicator were ranked across district and later rank correlation is calculated. According to ranks, there is correlation between high capita income and better branch network, Dashina Kannada. In fact, the distribution pattern of SHGs across district shows that, the linkages are high in the districts which have higher per capita income, better performance in the field of human index and higher number of NGOs. However, two district are exemption to it, the Kodagu district which has high income and better performance human index as low number of linkages, similarly Bidar district which has low income and human development index has high number of linkages.

The rank correlation shows that there is positive relationship between linkage and NGOs, this shows that wherever the NGOs had a base more number of SHGs are linked. Across district, Dashina Kannada, has highest 
number of SHGs linked (745), followed by Uttar Kannad, Bidar and Mysore in descending order and the lowest numbers linked in Kodagu district. Maping of linkage distribution shows across the region show that the coastal region followed by Mysore and North Karnataka in descending order. Within North-Karnataka the Hyderabad-Karnataka region has very less number of SHGs linked.

Table 7: Rank Correlation

\begin{tabular}{|c|c|}
\hline \multicolumn{2}{|c|}{ Rank correlation } \\
\hline Variables & Rank \\
\hline Linkage and Income & 0.1254 \\
\hline Linkages and Branches & 0.0065 \\
\hline Linkages and $\mathrm{NGOs}$ & 0.367986 \\
\hline Income and Branches & 0.459164 \\
\hline Income and NGOS & 0.20685 \\
\hline Branches and NGOs & 0.5901 \\
\hline
\end{tabular}

\section{Conclusion}

The evolution of commercial banks in India brings out that, though the social banking approach was initiated, but due to polticising and bevaracratisation of the credit delivery the objective could not serve. Contrary to it the formal banking credit has become high expensive and skewed towards asset holders and frequent borrowers. Even the credit programmes developed exclusively to weaker sections could not reach the credit timely to them. As a replacement to the problem, theoretically looking at information economics, the development of group lending and the linkage programme will provide in reduction of transaction of cost, timely credit and high recovery. The SHGs linkage programme is appropriate to reach the credit to the poor people and it has many advantages. However, with formal institutions are joining in promoting the which is target oriented and people do not have any professionalism in promoting the SHGs has caused great concern for quality. The commercial banks have not joined all of them, who have joined also identified only few branches for the purpose. 
However, the economy of the local area determines the linkage. Thus, the programme depends both on regional economy as well as institutions development.

\section{Reference}

Allen, F and D.Gale, (1995), "A Welfare Comparisons of Intermediaries and Financial Markets in Germany and the US" European Economic Review, 39, pp 179-209.

Belshaw, H (1931) The Provision of Credit with Special Reference to Agriculture, Auckland University College Text, No, 1 Cambridge.

Gold Smith, R.W., (1969) Financial Structure and Development, Yale University Press, New Haven.

Griffin, K. (1976) The Political Economy of Agrarian Change, An Essay on Green Revolution, Macmillian, London.

Hoff, K. and Stiglitz J.E. (1990) "Introduction: Imperfect Information and Rural Credit Markets - Puzzles and Policy Perspective", The World Bank Economic Review, vol 4(3).

Lipton, Michael, (1976) "Agricultural Finance and Rural Credit in Poor Countries", World Development, 4(7).

McKinnon, R.J., (1971) Money and Capital in Economic Development, Brooking Institution, Washington.

Nair, C.V. (1991), "Rural Credit - Emerging Issues and Challenges" I Surjeet Sing (ed,), Rural Credit: Issues for the Ninties, Oxford IBH, New Delhi.

Nanda; Y C (1994), "Significance of Establishing Linkages of SHGs with Banks" National Bank News Review, Mumbai.

Padmanabhan, K. P., (1988) Rural Credit: Lessons for Rural Bankers and Policy Makers, Intermediate Technology Publications, London.

Patrick, H.T., (1983) "Financial Development and Economic Growth" in Von-Pishke, Adams, Donald (ed.) Rural Financial Market in Developing countries, The John Hopkins University Press, London. 
Rajasekhar, D and Vysasulu, Vinod (1991)' The Half-Life of Cred it: Simulating Fund Flow in the Priority Sector' Economic and Political Weekly, September.

Rajasekhar, D (1996) 'Problems and Prospects of Group Lending in NGO Credit Programme in India, Savings and Development, $X X(1)$.

Reserve Bank of India (1993) "Report on Trends and Progress of Banking in India, 1991-92, RBI, Mumbai.

Shahiahan, K.M (1998)' Priority Sector Bank Lending: Some Important Issues' Economic and Political Weekly, XXXIII (42 and 43).

Stiglitz, J. E., and Weiss, Andrew, (1981) "Credit Rationing in Markets with Imperfect Information", The American Economic Review, 71(3).

Tandon P K (1988)" A note on Rural Indebtedness", Social Scientist, 16(4).

Veerashekharappa (1997) Institutional Finance for Rural Development, Rawath Publication, Jaipur.

Vyasulu, Vinod and Rajasekhar D,. (1991) 'Management Rural Credit: Issues in 1990s" International Journal of Development Banking, 9(1). 